\title{
THE EFFECT OF OESTROGEN UPON PREGNANCY AND PARTURITION IN THE MOUSE
}

\author{
D. G. PORTER \\ Department of Physiology, Royal Veterinary College, London, $\mathcal{N} . W .1$ \\ (Received 8th August 1969, revised 16th September 1969)
}

\begin{abstract}
Summary. Parturition in mice implanted with pellets of oestradiol on Day 16 of pregnancy occurred 1 day later than in cholesterol-treated controls. This prolongation of pregnancy was attributed to a reduction in the litter size occurring pre-partum due to 'jettisoning' of an average of $2 \cdot 2$ foetuses per mouse. Progesterone treatment was only partially effective in preventing the oestrogen-induced foetal loss.
\end{abstract}

\section{INTRODUCTION}

In the mouse, Parkes \& Bellerby (1927) and Parkes (1930) found that although oestrogen administered in late pregnancy caused abortion, continuous treatment was necessary and to secure this, a dose regimen of nineteen injections in $36 \mathrm{hr}$ was employed. However, in a pilot study to repeat this work, it appeared that continuous oestrogen treatment prolonged, rather than interrupted, pregnancy. After the commencement of this study, Dewar (1968) reported that pregnancy in the mouse was prolonged by almost a day $(P<0.05)$ using $50-\mu \mathrm{g}$ doses of oestradiol daily.

In view of this apparent contradiction of the earlier work, a detailed study of the effects of oestrogen upon pregnancy in the mouse was conducted.

\section{MATERIALS AND METHODS}

A total of 170 albino mice from an inbred colony of Tuck strain was used. Virgin females ( 30 to $35 \mathrm{~g}$ ) were placed with males, and examined the next morning for plugs (Day 1). The pregnant mice were anaesthetized on Day 16 with $1.25 \%$ aqueous tribromoethanol (Avertin, Winthrop) and a 5-mg (approx.) pellet of oestradiol-17 $\beta /$ cholesterol, alone, or together with a $10-\mathrm{mg}$ pellet of progesterone, or a 5-mg (approx.) pellet of cholesterol alone (controls) implanted subcutaneously at the back of the neck. The animals were weighed daily and examined for delivery. Some were allowed to go to term, others were killed on Day 19 and the contents of their uteri examined.

The pellets of oestradiol-17 $\beta$ :cholesterol were prepared by fusing a mixture of the two substances at the rate of $10 \mu \mathrm{g}$ oestradiol-17 $\beta: 1.0 \mathrm{mg}$ cholesterol. Progesterone pellets were obtained commercially. 


\section{RESULTS}

\section{Oestrogen pellets: specification}

The mean weight of oestrogen pellets used was $4.3 \mathrm{mg} \pm$ S.E. $0 \cdot 49$, i.e. containing $43 \mu \mathrm{g}$ oestradiol-17 $\beta$.

Two methods were used to assay the uptake of oestrogen from the pellets. In one, daily vaginal smears were taken after ovariectomized virgin mice had received a single pellet. Vaginal cornification persisted on average for 18.1 days \pm S.E. $2 \cdot 8$, indicating that, if all oestrogen in the pellets had been absorbed when cornification ceased, the maximum mean daily uptake had not exceeded $2 \cdot 4 \mu \mathrm{g}$. The second method was based upon the work of Martin \& Finn (1968). The technique used was to determine the rate of mitosis in the uterine endometrial stroma of progesterone-treated mice, $24 \mathrm{hr}$ after the implantation of an oestrogen pellet. The figures obtained were then compared with those using standard doses of oestrogen. The results confirmed that the uptake had not exceeded $2.5 \mu \mathrm{g} / 24 \mathrm{hr}$.

\section{Incidence of complete abortion}

The incidence of complete abortion, i.e. the complete emptying of the uterus before Day 19, was low in all groups (Table 1). Although the incidence was

\section{TABLE 1}

FREQUENCY OF COMPLETE ABORTION BEFORE DAY 19

\begin{tabular}{l|c|c|c}
\hline & & \multicolumn{2}{|c}{ Aborted } \\
\cline { 3 - 4 } \multicolumn{1}{c|}{ Group } & Mice & No. & $\%$ \\
\hline Control & 36 & 2 & $5 \cdot 5$ \\
Oestradiol & 94 & 10 & $10 \cdot 6$ \\
Oestradiol + progesterone & 40 & 1 & $2 \cdot 5$ \\
\hline
\end{tabular}

somewhat higher among the oestrogen-treated group, the difference was not statistically significant.

Effect of oestradiol-17 $\beta$ on gestation length

The effect of oestradiol treatment upon gestation length is shown in Table 2. Oestrogen caused a statistically significant increase in the gestation length.

TABLE 2

THE EFFEGT OF OESTRADIOL ON GESTATION LENGTH

\begin{tabular}{l|c|c|c}
\hline \multicolumn{1}{c|}{ Group } & No. of mice & $\begin{array}{c}\text { Mean gestation length } \\
(\text { days } \pm \text { S.E. })\end{array}$ & $P$ \\
\hline Control & 10 & $\begin{array}{c}20 \cdot 0 \pm 0 \cdot 00 \\
21 \cdot 0 \pm 0.12\end{array}$ & $<0 \cdot 001$ \\
Oestradiol & 11 & \\
\hline
\end{tabular}


Effect of oestradiol $-17 \beta$ on litter size

The oestradiol-treated animals delivered smaller litters than the controls. Among fourteen control litters, the mean number of pups was $9 \cdot 4 \pm$ S.E. 0.53, whereas among sixteen litters from oestrogen-treated mice the mean number was $6 \cdot 9 \pm$ S.E. $0 \cdot 70$ pups. This difference was significant at the $1 \%$ level.

TABLE 3

EFFECT OF OESTRADIOL AND OESTRADIOL + PROGESTERONE ON NUMBER OF FOETUSES IN THE UTERUS: DAY 19

\begin{tabular}{l|c|c}
\hline \multicolumn{1}{c|}{ Group } & No. of mice & $\begin{array}{c}\text { Mean no. of foetuses } \\
\pm S . E .\end{array}$ \\
\hline Oestradiol & 44 & $7.9 \pm 0.53$ \\
Control & 26 & $\left.\begin{array}{r}10 \cdot 0 \pm 0.60 \\
9 \cdot 1 \pm 0.83\end{array}\right\} \mathrm{NS}$ \\
Oestradiol + progesterone & 21 & \\
\hline
\end{tabular}

NS-not significant.

The smaller litters among the oestradiol-treated mice might be attributable to a higher incidence of foetal death in utero. This would result in the delivery of dead foetuses which would promptly be eaten by the mother and hence would not be counted. Alternatively, it might be due to pre-partum foetal loss (i.e. incomplete abortion). In order to differentiate between these possible causes, mice given implants on Day 16 were killed on Day 19 and the contents

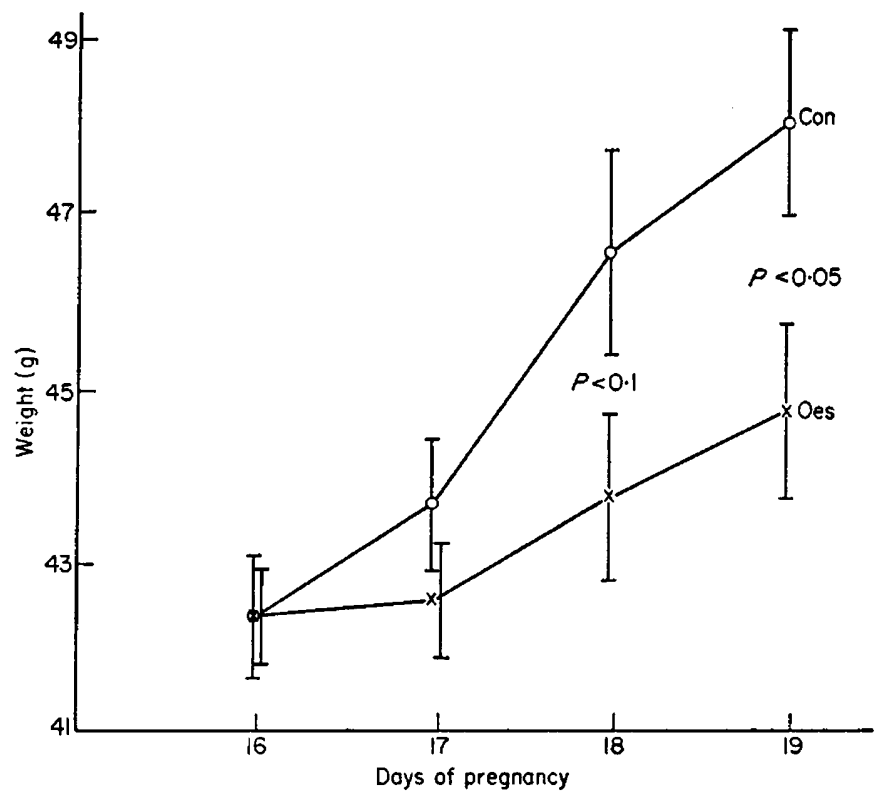

TExT-PIG. 1. Graph showing weight gain of pregnant mice after receiving subcutaneous implants of either oestradiol or cholesterol on Day 16 of pregnancy. Con: control animals treated with cholesterol pellets; Oes: animals treated with oestradiol pellets. Number of animals at each point: twenty-six to thirty-nine. 
of their uteri recorded. The incidence of foetal death in utero was low in all groups (i.e. $1.9 \%$ in the control, $6.6 \%$ in the oestrogen-treated and $2.2 \%$ in the oestradiol + progesterone-treated group), and the differences were not significant.

However, the total number of foetuses in utero on Day 19 was significantly less $(P<0.01)$ in the oestrogen-treated group than in the controls (Table 3$)$. The

TABLE 4

EFFECT OF OESTRADIOL ON FOETAL AND PLACENTAL WEIGHT : DAY 19

\begin{tabular}{c|c|c}
\hline Group & $\begin{array}{c}\text { Mean foetal wt } \\
(g \pm S . E .)\end{array}$ & $\begin{array}{c}\text { Mean placental wt } \\
(g \pm S . E .)\end{array}$ \\
\hline Controls (fourteen mice) & $1 \cdot 23 \pm 0.03$ & $0.09 \pm 0.004$ \\
Oestradiol (twelve mice) & $1 \cdot 19 \pm 0.04$ & $0 \cdot 10 \pm 0.003$ \\
\hline
\end{tabular}

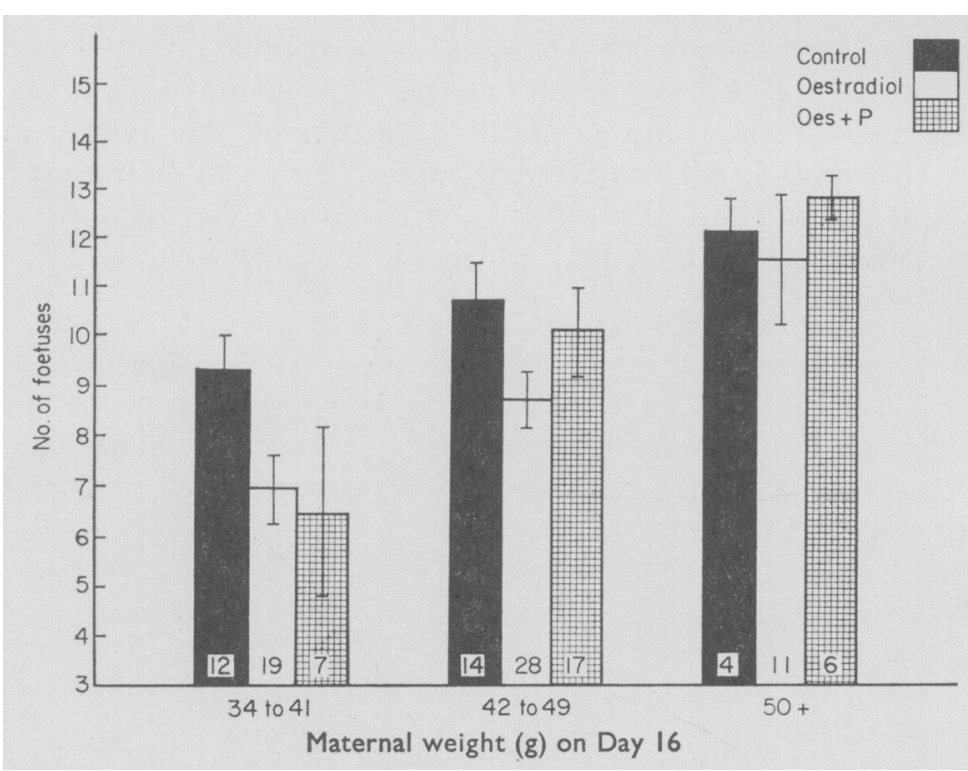

Text-pig. 2. Histogram showing number of foetuses found in utero on Day 19 of pregnancy after cholesterol (control), oestradiol and oestradiol-progesterone treatment, in relation to the maternal weight on Day 16 at the commencement of the experiment. Numbers above the abscissa indicate number of animals in each group.

presence of placental scars, or retained placentae in the cervical segment of the uterine horns indicated that the average difference of $2 \cdot 2$ foetuses was due to incomplete abortion. This conclusion is supported by the data on weight gain of the mice following treatment (Text-fig. 1). The weights of the oestrogentreated mice on Days 18 and 19 were significantly lower than the controls, despite the fact that their mean weights at the commencement of the experiment were the same. 
The difference in the mean weight of oestrogen-treated and control mice could be accounted for by the loss of $2 \cdot 2$ foetuses, but in order to determine whether there was an additional effect of oestrogen upon the foetuses and placentae which were retained, these were weighed (Table 4). The differences between the means of the two groups were not significant.

\section{Effect of progesterone upon oestrogen-induced foetal loss}

Implanting a pellet of progesterone simultaneously with the oestrogen pellet reduced the foetal loss (Table 3) but not significantly. Thus the number of foetuses in utero on Day 19 in the oestrogen + progesterone group was intermediate between that of the oestrogen and the control groups and differed from neither of them significantly. The uptake of progesterone between Days 16 and 19 , determined by weighing the pellet before and after treatment, was $0.9 \mathrm{mg}$ \pm S.E. 0.07 .

When the number of foetuses in utero on Day 19 was plotted against maternal weight on Day 16, it was found (Text-fig. 2) that the greatest effect of oestrogen in causing foetal loss appeared to be upon females with the lowest weight on Day 16. The least effect of progesterone in reducing foetal loss was also in this group.

\section{DISCUSSION}

The above results confirm those of Dewar (1968) that oestrogen treatment slightly prolongs pregnancy in the mouse. Although this would seem to contradict the findings of Parkes \& Bellerby (1927) and Parkes (1930), the results also reveal that this contradiction is only apparent.

Although prompt and complete abortion following oestrogen treatment in the present experiments was uncommon, partial abortion was a frequent occurrence. Thus, on average, the oestrogen-treated mice delivered $2 \cdot 2$ foetuses before term, but the major proportion of the litters were retained and delivered safely at term, albeit somewhat late. Thus, this process might be termed foetal 'jettisoning' rather than premature or protracted labour. A similar phenomenon has been described in the rat after both oestrogen treatment (Hain, 1935) and ovariectomy (Csapo, 1969).

Hence, it would seem that the prolongation of pregnancy by oestrogen is consistent with the view that oestrogen increases uterine activity. Biggers, Curnow, Finn \& McLaren (1963) and Dewar (1968) have shown that gestation length in the mouse is inversely related to litter size. McLaren \& Michie (1963) found that the total mass, rather than the number of the conceptuses, is important, and McLaren (1967) has indicated further that foetal, rather than placental, mass is the primary factor. The reduction of litter size by foetal 'jettisoning' (i.e. oestrogen activation of the myometrium) thus served to postpone the time when the remainder of the litter is delivered. At present, it is not possible to explain how the uterus becomes activated to expel one or two foetuses and then de-activated to retain the remainder of the litter.

The only factor at present known to maintain pregnancy in the mouse is progesterone. However, progesterone was only partially effective in preventing the oestrogen-induced foetal loss, although this may have been due to inade- 
quate uptake. It is interesting that progesterone seemed to be least effective in preventing foetal loss among mice with the lowest body weight on Day 16 (Text-fig. 2), which was the group most susceptible to the effects of oestrogen. If the maternal weight on Day 16 is accepted as an indication of the number of foetuses in utero at the beginning of the experiment, then it would appear that oestrogen is most effective in causing foetal loss when the litter is small. This suggests that the 'safety' margin of progesterone production increases with increased number of foetuses.

If oestrogen had a greater effect in initiating delivery in mice with small litters, this suggests that it was not acting synergistically with the foetal mass effect (McLaren, 1967).

\section{REFERENCES}

Biggers, J. D., Gurnow, R. N., Finn, C. A. \& MaLaren, A. (1963) Regulation of the gestation period in mice. F. Reprod. Fert. 6, 125.

Csapo, A. (1969) The luteo-placental shift, the guardian of pre-natal life. Postgrad. med. 7. 45, 57.

Dewar, A. D. (1968) Litter size and the duration of pregnancy in mice. Q.Jl exp. Physiol. 53, 155.

HaIN, A. M. (1935) The physiology of pregnancy in the rat: an hormonal investigation into the mechanism of parturition. Effect on the female rat of the ante-natal administration of oestrin to the mother. Q. $7 l$ exp. Physiol. 25, 131.

McLaren, A. (1967) Effect of foetal mass on gestation period in mice. F. Reprod. Fert. 13, 349.

McLaren, A. \& Michiz, D. (1963) Nature of the systemic effect of litter size on gestation period in mice. F. Reprod. Fert. 6, 139.

Martin, L. \& FinN, C. A. (1968) Hormonal regulation of cell division in epithelial and connective tissues of the mouse uterus. F. Endocr. 41, 363.

Parkes, A. S. (1930) On the synergism between oestrin and oxytocin. F. Physiol., Lond. 69, 463.

Parkes, A. S. \& Bellerby, C. W. (1926) Studies on the internal secretions of the ovary. II. The effects of injection of the oestrus producing hormone during pregnancy. 7. Physiol., Lond. 62, 145. 